\title{
PENGAWASAN TERHADAP KINERJA PEGAWAI
}

\author{
Sevia puspita sari \\ e-mail: seviapuspitasari77@gmail.com[2] \\ Universitas Negeri Padang
}

\begin{abstract}
Abstrak Masalah tentang kepuasan kerja tidak lepas dari karyawan itu sendiri dan perusahaan dimana karyawan itu bekerja misalnya apabila karyawan dari perusahaan banyak mengundurkan diri, Maka perusahaan tersebut perlu melakukan proses rekrutmen kembali untuk mendapatkan karyawan baru. Hal-hal tersebut tentu membuang buang waktu yang lama dan biaya. Selain itu juga ada efek negative yang harus perusahaan tanggung, mulai dari menirunnya pruktivitas kerja hingga citra buruk perusahaan. Oleh karena itu, untuk menanggulangi kondisi tersebut, perusahaan perlu mengetahui apa saja yang menjadi penyebab utama karyawan meninggalakan perusahaan Rendahnya tinggat kinerja pegawai akan menimbulkan masalah bagi perusahaan yang akan mengalami kerugiaan besar bagi perusaan dimana pegawai itu bekerja salah satu strategi untuk membuat karyawan merasa puas dalam bekerja adalah pemberian insentif dan motivasi untuk kariawan yang berbakat dalam bekerja.
\end{abstract}

Kata kunci : pengawasan,kinerja

\section{PENDAHULUAN}

Ketercapaian dan keberhasilan suatu dalam mencapai tujuan tidak terlepas dari faktor sumber daya manusianya. Istilah sumber daya manusia dapat disamakan artinya dengan pegawai atau karyawan, yaitu orang yang mengerjakan suatu pekerjaan dalam suatu organisasi, baik organisasi yang bergerak dalam bidang pemerintahan maupun bidang swasta. Setiap pegawai dalam organisasi tentunya memiliki tugas dan tanggung jawab yang harus dilaksanakan sesuai dengan tuntutan organisasi atau lembaga. Baik atau buruknya pekerjaan seorang pegawai dapat dilihat dari kinerjanya. Kinerja pegawai merupakan suatu hasil yang dicapai oleh pegawai tersebut dalam pekerjaanya menurut kriteria tertentu yang berlaku untuk suatu pekerjaan tertentu. Menurut Robbins (2003) bahwa kinerja pegawai adalah sebagai fungsi dari interaksi antara kemampuan dan motivasi. Dalam studi manajemen kinerja pekerja atau pegawai ada hal yang memerlukan pertimbangan yang penting sebab kinerja individual seorang pegawai dalam organisasi merupakan bagian dari kinerja organisasi, dan dapat menentukan kinerja dari organisasi tersebut. Berhasil tidaknya kinerja pegawai yang telah dicapai organisasi tersebut akan dipengaruhi oleh tingkat kinerja dari pegawai secara individu maupun kelompok. Kinerja (ferformance) merupakan perilaku organisasional yang secara langsung berhubungan dengan produksi barang atau penyampaian jasa. Kinerja seringkali difikirkan sebagai pencapaian tugas, 
dimana istilah tugas sendiri berasal dari pemikiran aktivitas yang dibutuhkan oleh pekerja (Gibson, 1997). Yukl (1998) memakai istilah proficiency yang mengandung arti yang lebih luas. Kinerja mencakup segi usaha, loyalitas, potensi, kepemimpinan, dan moral kerja. Profisiensi dilihat dari tiga segi, yaitu: perilaku-perilaku yang ditunjukan seseorang dalam bekerja, hasil nyata atau outcomes yang dicapai pekerja, dan penilaian-penilaian pada faktor-faktor seperti motivasi, komitmen, inisiatif, potensi kepemimpinan dan moral kerja. Gibson (1997) mendefinisikan kinerja sebagai hasil dari pekerjaan yang terkait dengan tujuan organisasi seperti, kualitas, efesiensi, dan kriteria efektifitas lainya. Kinerja merefleksikan seberapa baik dan seberapa tepat seorang individu memenuhi permintaan pekerjaan. kinerja dipandang sebagai hasil yang bersifat kualitatif dan kuantitatif. Berhasil tidaknya kinerja yang telah dicapai oleh organisasi dipengaruhi oleh tingkat kinerja pegawai secara individu maupun kelompok, dimana kinerja diukur dengan instrumen yang dikembangkan dalam studi yang tergantung dengan ukuran kinerja secara umum, kemudian diterjemahkan kedalam penilaian perilaku secara mendasar yang dapat meliputi berbagai hal yaitu: kuantitas pekerjaan, kualitas pekerjaan, pendapat atau pernyataan yang disampaikan, keputusan yang diambil dalam melakukan pekerjaan dan deskripsi pekerjaan. Untuk mengukur kinerja secara individual, McKenna dan Beech (1995) ada beberapa indikator, indikator-indikator dari kinerja yang sering dipergunakan untuk menilai kinerja individu pegawai menurut McKenna dan Beech adalah: Pengetahuan, kemampuan dan keterampilan pada pekerjaan/kompeten,Sikap kerja, diekspresikan sebagai antusiasme, komitmen dan motivasi, Kualitas pekerjaan, Interaksi, misalnya keterampilan komunikasi dan kemampuan untuk berhubungan dengan orang lain dalam satu tim. Tanpa adanya kinerja pegawai yang maksimal maka akan sulit bagi sebuah organisasi untuk mencapai tujuan yang telah ditetapkan, maka perlu adanya pembinaan dari pimpinan terhadap kinerja pegawai. Pengawasan terhadap kinerja pegawai adalah usaha atau tindakan yang dilakukan untuk mengetahiseorang pegawa dalam melakukan pekerjaan mengembangkan kinerja pegawai mulai dari peningkatan pengetahuan, keterampilan, kompetensi serta tanggung jawab pegawai dalam melaksanakan pekerjaan yang dimilikinya untuk mencapai tujuan dengan hasil yang lebih baik. Kinerja pegawai sangatlah penting bagi setiap pegawai dalam suatu organisasi, karena dengan adanya pengawasan pimpinan dapat mengetahui atau mengidentifikasi masalah atau kesulitan yang dialami oleh pegawai, serta dengan pengawasan juga dapat menciptakan cara kerja yang maksimal, meningkatkan kualitas, keterampilan serta semangat kerja yang tinggi pada pegawai 
dan menciptakan ketaatan atas norma dan peraturan yang berlaku di dalam organisasi. Pimpinan memiliki tanggung jawab yang besar dalam melakukan pembinaan kepada pegawainya.. Pengawasan oleh pimpinan dilakukan terhadap setiap aspek kerja dari pegawai, apakah pekerjaan yang dilakukannya sesuai dengan apa yang direncanakan dan diharapkan oleh lembaga organisasinya. kegiatan pembinaan yang dilakukan oleh pimpinan masih belum optimal sehingga membuat kinerja pegawai kurang maksimal, hal ini terlihat dari beberapa fenomena yang menunjukkan adanya masalah terkait dengan pembinaan kinerja pegawai diantaranya: Masih adanya sikap pegawai yang kurang kreatif dalam bekerja. Namun kurang adanya bimbingan yang diberikan oleh pimpinan. masih adanya pegawai yang sering terlambat datang dan sering meninggalkan kantor pada saat jam kerja kantor. Namun pimpinan jarang melakukan teguran dan pemberian sanksi yang tegas terhadap pegawai tersebut. ada beberapa pegawai yang kurang mau membantu pegawai lain dan juga masih adanya pegawai yang kurang mampu mengontrol emosinya sehingga adanya rasa kurang suka antar sesama pegawai. Hal tersebut dibiarkan saja oleh pimpinan tanpa memberikan bimbingan dan arahan kepada masing-masing pegawai yang bersangkutan.masih adanya pegawai yang menunda-nunda pekerjaannya, sehingga pekerjaan tersebut tidak selesai tepat waktu dan menumpuk, serta masih rendahnya pemberian petunjuk atau arahan yang jelas oleh pimpinan terhadap pekerjaan yang harus dikerjakan pegawai. Masih ada pegawai yang kurang berinisiatif dalam membantu pegawai lain dalam kegiatan rutinitas tahunan lembaga.

\section{PEMBAHASAN}

Kinerja berasal dari kata Job performance yaitu prestasi kerja yang dicapai seseorang. Performance diterjemahkan menjadi kinerja, juga berarti prestasi kerja, pelaksanaan kerja,pencapaian kerja atau hasil kerja, penampilan kerja (Lembaga Administrasi Negara ; 1992) Sedangkan menurut anwar prabu $(2004 ; 67)$ pengertian kinerja ( prestasi kerja ) adalah hasil kerja secara kualitas dan kuantitias yang dicapai oleh seorang pegawai dalam melaksanakan tugasnya sesuai dengan tanggung jawab sesuai dengan tanggung jawab yang diberikan kepadanya. Dalam melakukan suatu pekerjaan, seorang pegawai hendaknya memiliki kinerja yang tinggi. Akan tetapi hal tersebut sulit untuk dicapai, bahkan banyak pegawai yang memiliki kinerja yang rendah atau semakin menurun walaupun telah banyak memiliki pengalaman kerja 
dan lembaga pun telah banyak melakukan pelatihan maupun pengembangan terhadap sumber daya manusianya, untuk dapat meningkatkan kemampuan dan motivasi kerja pegawainya. Kinerja pegawai yang rendah akan menjadi sutau permasalahan bagi sebuah organisasi atau lembaga, karena kinerja yang dihasilkan pegawai tidak sesuai dengan yang diharapkan oleh organisasi. Untuk memberikan gambaran tentang kinerja pegawai, berikut ini adalah beberapa penjelasan yang berkaitan dengan kinerja pegawai. Dalam kamus bahasa inggris (Melinda ; 2005) Kinerja didalam kamus bahasa Indonesia (1994; 503) dikatakan bahwa kinerja merupakan : (1) sesuatu yang dicapai (2) prestasi yang diperlihatkan (3) Kemampuan kerja. Sehingga dapat disimpulkan bahwa kinerja merupakan hasil kerja yang dihasilkan oleh pegawai atau karyawan dalam melakukan tugas dan tanggung jawabnya. Grounlud dalam bukunya "human competence engineering worthly performance" memberikan pendapatnya seperti yang dikutip oleh arif rahman (1997; 26) "kinerja adalah penampilan perilaku kerja yang ditandai oleh keluwesan gerak, ritme atau urutan kerja yang sesuai dengan prosedur sehingga diperoleh hasil yang memenuhi syarat berkualitas, kecepatan dan jumlah". Kinerja juga dapat diartikan sebagai prestasi yang dapat dicapai organisasi dalam suatu periode tertentu. Prestasi yang dimaksud adalah efektifitas operasional organisasi baik dari segi manajerial maupun ekonomis operasional. Dengan kinerja kita dapat mengetahui sampai seberapa besar peringkat prestasi keberhasilan atau bahkan mungkin kegagalan seseorang karyawan dalam menjalankan amanah yang diterimanya. Sedangkan kinerja sumber daya manusia merupakan istilah yang bersal dari kata Job Performance atau Actual Performance artinya prestasi kerja atau prestasi sesungguhnya yang dicapai seseorang. definisi kinerja karyawan yang dikemukakan oleh Bambang Kusriyanto (1991 : 3) dalam Evaluasi Kinerja Sumber Daya Manusia (Mangkunegara, 2005 : 9) adalah "Perbandingan hasil yang dicapai dengan peran serta tenaga kerja persatuan waktu (lazimnya per jam)". Selanjutnya Mangkunegara (2005 : 9), mengemukakan bahwa : "Kinerja karyawan (prestasi kerja) adalah hasil kerja secara kulaitas dan kuantitas yang dicapai oleh seseorang karyawan dalam melaksanakan tugasnya sesuai dengan tanggung jawab yang diberikan kepadanya". Kinerja (performance) dapat diartikan sebagai penampilan kerja seorang pegawai terhadap organisasi dimana ia bernaung dan merupakan gabungan antara kemampuan dan usaha yang dilakukan untuk mengahsilkan kinerja terbaik. 
Berdasarkan pengertian-pengertian kinerja di atas, maka dapat dinyatakan bahwa kinerja adalah kemampuan untuk merealisasikan kemampuan kerja pegawai sesuai dengan tugas dan tanggung jawab dari pekerjaan yang diembannya. Maka peningkatan kinerja pegawai adalah proses untuk meningaktkan kemampuan kerja, penampilan kerja atau performance kerja seseorang yang dapat dilakukan dengan berbagai cara.

\section{Faktor-faktor Pencapaian Kerja}

Faktor-faktor yang mempengaruhi pencapaian kinerja adalah faktor kemampuan (ability) dan faktor motivasi (motivation). Hal ini sesuai dengan pendapat Keith Davis dalam Mangkunegara (2000 : 67) yang merumuskan bahwa:

\section{a. Faktor Kemampuan (Ability)}

Secara psikologis, kemampuan (ability) terdiri dari kemampuan potensi (IQ) dan kemampuan reality (knowledge + skill). Artinya, pemimpin dan karyawan yang memiliki IQ di atas rata-rata (IQ 110 - 120) apalagi IQ superior, very superior, gifted dan genius dengan pendidikan yang memadai untuk jabatannya dan terampil dalam mengerjakan pekerjaan sehari-hari, maka akan lebih mudah mencapai kinerja maksimal.

\section{b. Faktor Motivasi (Motivation)}

Motivasi diartikan suatu sikap (attitude) pimpinan dan karyawan terhadap situasi kerja (situation0 di lingkungan organisasinya. Mereka yang bersikap positif (pro) terhadap situasi kerjanya akn menunjukkan motivasi kerja tinggi dan sebaliknya jika mereka bersikap negative (kontra) terhadap situasi kerjanya akan menunjukkan motivasi kerja rendah. Situasi kerja yang dimaksud mencakup antara lain hubungan kerja, fasilitas kerja, iklim kerja, kebijakan pimpinan, pola kepemimpinan kerja dan kondisi kerja.

Menurut A. Dale Timple (1992 ; 31) dalam Evaluasi Kinerja Sumber Daya Manusia (Mangkunegara, 2005 : 15) mengemukakan faktor-faktor kinerja yaitu :

\section{Faktor Internal}

Faktor Internal (disposisional) yaitu faktor yang dihubungkan dengan sifat-sifat seseorang, misalnya kinerja seseorang baik disebabkan karena mempunyai kemampuan tinggi dan seseorang itu tipe pekerja keras, sedangkan seseorang 
mempunyai kinerja jelek disebabkan orang tersebut tidak memiliki upaya-upaya untuk memperbaiki kemampuannya.

\section{Faktor Eksternal}

Faktor eksternal yaitu faktor-faktor yang mempengaruhi kinrja seseorang yang berasal dari lingkungan. Seperti perilaku, sikap, tindakan-tindakan rekan kerja, bawahan atau pimpinan, fasilitas kerja dan iklim organisasi.

Mangkunegara (2005 ; 160 mengemukakan bahwa faktor-faktor penentu kinerja (prestasi kerja individu) dalam organisasi adalah faktor individu dan faktor lingkungan kerja organisasi.

\section{a. Faktor Individu}

Secara psikologis, individu yang mormal adalah individu yang memiliki integritas yang tinggi antara fungsi psikis (rohani) dan fisiknya (jasmaniah). Dengan adanya integritas yang tinggi antara fungsi psikis dan fisik, maka individu tersebut memiliki konsentrasi diri yang baik. Konsentrasi yang baik ini merupakan modal utama individu manusia untuk mampu mengelola dan mendayagunakan potensi dirinya secara optimal dalam melaksanakan kegiatan atau aktivitas kerja sehari-hari dalam mencapai tujuan organisasi.

\section{b. Faktor Lingkungan Organisasi}

Faktor lngkungan kerja organisasi sangat menunjang bagi individu dalam mencapai prestasi kerja. Faktor lingkungan organisasi yang dimaksud antara lain uraian jabatan yang jelas, autoritas yang memadai, target kerja yang menantang, pola komunikasi kerja efektif, hubungan kerja harmonis, iklim kerja respek dan dinamis, peluang berkarier dan fasilitas kerja yang relatif memadai.

Sedangkan John Locke dalam teori lingkungan berpandangan bahwa hanya faktor lingkungan yang sangat menentukan seorang individu mampu berprestasi baik atau tidak. menentukan kinerja pegawai juga dapat dilihat dari kreatifitas pegawai. Kreatifitas adalah kemampuan untuk mengolah informasi sehingga informasi tersebut bisa bermakna, bermanfaat, dan menjadi sesuatu hal yang baru.Kreativitas seseorang akan bermanfaat jika didukung oleh lingkungan sekitarnya.jadi kreatifitas yang didukung oleh organisasi dan lingkungan sekitarnya akan dapat meningkatkan kinerja seseorang dan secara langsung juga dapat menciptakan efektivitas organisasi. 


\section{Unsur-unsur Kinerja}

Selanjutnya B Sastrohardiwiryo (2002) menjelaskan bahwa umumnya unsur-unsur kinerja adalah sebagai berikut :

1. Kesetiaan

Kesetiaan yang dimaksud adalah tekad dan kesanggupan didalam mentaati, melaksanakan dan mengamalkan sesuatu yang ditaati dengan penuh kesadaran dan tanggung jawab. Tekad dan kesanggupan tersebut harus dibuktikan dengan sikap dan tingkah laku tenaga kerja yang bersangkutan dengan kegiatan sehari-hari serta dalam perbuatan melaksanakan tugas dan pekerjaan yang dibebankan kepadanya. Kesetiaan tenaga kerja terhadap suatu perusahaan sangat berhubungan dengan pengabdiannya. Pengabdian yang dimaksud adalah sumbangan pikiran dan tenaga yang ikhlas dengan mengutamakan kepentingan publik diatas kepentingan pribadi.

2. Prestasi kerja

Prestasi kerja merupakan hasil kerja yang dicapai oleh seorang tenaga kerja dalam melaksanakan tugas dan pekerjaan yang dibebankan kepadanya. Pada umumnya prestasi kerja seorang tenaga kerja dipengaruhi oleh kecakapan, keterampilan pengalaman, dan kesanggupan tenaga kerja yang bersangkutan.

3. Tanggung jawab

Tanggung jawab adalah kesanggupan seorang tenaga kerja dalam menyelesaikan tugas dan pekerjaan yang diserahkan kepadanya dengan sebaik-baiknya dan tepat waktu. Serta dapat mengambil resiko atas keputusan yang diambilnya atau tindakan yang dilakukannya.

4. Ketaatan

Ketaatan adalah kesanggupan seorang tenaga kerja untuk mentaati segala aturan dan ketentuan serta pertauran perundang-undangan yang berlaku, mentaati peraturan kedinasan yang diberikan oleh atasan yang berwenang, serta kesanggupan untuk tidak melanggar larangan yang telah ditentukan oleh perusahaan maupun pemerintah, baik secara tertulis maupun tidak tertulis. 


\section{Kejujuran}

Merupakan ketulusan hati tenaga kerja dalam melaksanakan tugas dan pekerjaan serta kemampuan untuk tidak menyalah gunakan wewenang yang telah dibebankan kepadanya.

6. Kerjasama

Merupakan kemamuan tenaga kerja untuk bekerja sama dengan orang lain dalam menyelesaikan tugas dan pekerjaan yang telah diamanatkan, sehingga mencapai daya guna dan hasil guna yang sebesar-besarnya.

7. Prakarsa

Adalah kemampuan seorang tenaga kerja untuk mengambil suatu keputusan ataupun tindakan yang diperlukan tanpa diperintah oleh manajemen lainnya.

8. Kepemimpinan

Adalah kemampuan yang dimiliki seorang tenaga kerja untuk meyakinkan orang lain (tenaga kerja lain) sehingga dapat dikerahkan secara maksimal untuk melaksanakan tugas pokok. Penilaian unsure kepemimpinan bagi tenaga kerja yang mempunyai keyakinan dalam perusahaan, bagi top manajemen. Middle manajemen maupun lower manajemen.

\section{Standar Pengukuran Kinerja}

Berbicara mengenai penilaian kerja, erat kaintannya dengan standar kinerja, karena standar kinerja perlu dirumuskan untuk dijadikan acuan dalam comparative standar (standar perbandingan). Standar perbandingan terhadap apa yang dicapai dengan apa yang diharapkan. Dengan kata lain standar tersebut dapat dijadikan patokan dalam menilai tanggung jawab terhadap apa yang dilakukan. Agus Dharman (1991) mengungkapkan pengukuran kinerja dapat berfungsi sebagai target / sasaran, sebagai informasi yang dapat diguanakan para pegawai dalam mengarahkan usaha-usaha mereka melalui serangkaian prioritas tertentu. Dengan demikian peningkatan kinerja yang efektif dapat mempengaruhi sekaligus dua hal yaitu : kualitas kerja dan produktifitasDalam melakukan penilaian terhadap kinerja pegawai ada beberapa hal yang dijadikan sebagai tolak ukur atau standar yang sering digunakan dalam melakukan penilaian kinerja. Standar kinerja itu sendiri dirumuskan sebagai tolak ukur untuk mengadakan perbandingan antara apa yang telah dilakukan dengan apa yang diharapkan dan kaitannya dengan pekerjaan atau jabatan yang telah dipercayakan kepada seseorang. Standar tersebut dapat dijadikan ukuran dalam mengadakan pertanggungjawaban terhadap apa yang dilakukan. 


\section{Manfaat Pengukuran Kinerja}

Pengukuranmerupakan hal yang penting dalam manajemen program secara keseluruhan, karena kinerja yang dapat diukur akan mendorong pencapaian kinerja tersebut. Pengukuran kinerja yang dilakukan secara berkesinambungan memberikan umpan balik (Feedback) yang merupakan hal penting dalam upaya perbaikan secara terus-menerus dan mencapai keberhasilan dimasa yang akan dating. Melalui pengukuran kinerja diharapkan instansi atau lembaga manapun dapat mengetahui kinerja dalam suatu periode tertentu. Beberapa manfaat pengukuran kinerja adalah meningkatkan kualitas jasa dan produk,memastikan akuntabilitas dan pengendalian meningkatkan kualitas praktek manajemen, memformulasikan kebijakan, merencanakan dan menggerakan, meyakinkan ekuitas dalam distribusi dan eksesibilitas atas jasa.

\section{KESIMPULAN DAN SARAN}

Kinerja adalah hasil kerja yang dapat dicapai oleh seseorang atau kelompok orang dalam suatu perusahaan sesuai dengan wewenang dan tanggung jawab masing-masing dalam upaya pencapaian tujuan perusahaan Penilaian kinerja adalah suatu proses penilaian tentang seberapa baik pekerja atau karyawan telah melaksanakan tugasnya dalam periode waktu tertentu. Tujuan penilaian kinerja adalah untuk memperbaiki dan meningkatkan kinerja organisasi melalui peningkatan kinerja SDM dari organisasi. Penilaian prestasi kerja merupakan suatu proses rangkaian kinerja yang berawal dari penyusunan prestasi kerja yang berupa Sasaran Kerja Pegawai (SKP) yang penetapan tolak ukur yang meliputi aspek kuantitas, kualitas, waktu, dan biaya dari setiap tugas jabatan. Penilaian kinerja sangat berperan penting bagi pegawai/karyawan untuk mengukur kinerja masing-masing dalam mengembangkan dan meningkatkan kualitas kerja, sehingga dapat diambil tindakan yang efektif untuk peningkatan kinerja tersebut. Penilaian kinerja bermanfaat bagi semua pihak yang berkepentingan dan berada di instansi atau organisasi tersebut, yaitu orang yang dinilai (pegawai/karyawan), penilai (atasan, supervisor, pimpinan, . Pelaksanaan penilaian SKP dilakakukan dengan cara membandingkan antara realisasi kerja dengan target yang telah ditetapkan. Dalam melakukan penilaian dilakukan analisis terhadap hambatan pelaksanaan pekerjaan untuk mendapatkan umpan balik serta menyusun rekomendasi perbaikan dan menetapkan hasil penilaian. Beberapa hambatan yang terjadi dalam penilaian adalah karena adanya kendala dalam realisasi anggaran, dan hierarki organisasi yang panjang sehingga membuat proses penilaian yang lama.Karena pegawa/karyawan masih belum mengerti cara menggunakan system penilaian kinerja dan perlunya penilaian kinerja ini, maka seharusnya pemerintah atau instansi yang bersangkutan memberikan pelatihan dan pengetahuan terhadap tata cara pengisian Penilaian Kinerja SKP kepada seluruh pegawai instansi agar pegawai lebih mengerti dan sadar akan pentingnya penilaian kinerja ini.Melakukan pembenahan dan revisi terhadap aturan pelaksanaan Penilaian Kinerja dalam Instansi terkait agar aturan atau sistem yang dijalankan bias akurat dan dapat di ukur dengan lebih baik. 


\section{DAFTAR PUSTAKA}

Ermita, \& Anisah. (2013). Pembinaan dan Kinerja Guru Sekolah Menengah Atas Negeri (SMAN). Pedagogi

Robbins, S. P. 2003. Perilaku Organisasi. (terjemahan). Buku 1. Edisi Indonesia.jakarta : PT. Gramedia

Gibson \& Donelly (1997). Organisasi, Jilid 1, edisi 5, Jakarta : Penerbit Erlangga.

Yukl,garry, 1998. Kepemimpinan dalam Organisasi. Jakarta : prenhallindo, 1998.

McKenna, E \& Beech, n, 1995, The Essence Of Human Resource Management, Prentice Hall Internasional Ltd.

LAN ( Lembaga Administrasi Negara ) RI, (1992), Budaya Organisasi dan Peningkatan Kenerja. Jakarta : Pustaka Harapan.

A.A Anwar Prabu Mangkunegara. 2004. Manajemen Sumber Daya Manusia. Perusahaan Cetakan Pertama, penerbit,penerbit Pt. Remaja Rsodakarya. Bandung.

Arifin Abdul Rahman (1997), Pengembangan \& Filosofi Kepemimpinan Kerja, Bharata, Jakarta.

Krisyanto, Edy. (2005). Pengaruh Gaya Kepemimpinan Dan Kepuasan Kerja Terhadap Turnover Intention Karyawan PT Garuda Karya Mandiri. Jurnal Ilmiah Ilmu Pendidikan.

A.Anwar Prabu Mangkunegara (2000) . Manajemen Sumber Daya Manusia Perusahaan. Bandung :Remaja Rosdakarya.

Sastrohadiwiryo, Siswanto. 2002. Manajemen Tenaga Kerja Indonesia (Pendekatan Administratif Dan Operasional ). Jakarta: Sinar Grafika Offset. 